Sanglap Translation Section

\title{
Chaora Bhaora
}

\author{
Sarada Prasad Kisku
}

(originally published in Santali as Chaora Bhaora, 2008)

\author{
Translated by Nishaant Choksi
}

\section{Section Editor's Comments}

Samrat Sengupta

Literary translation can be a political act with immanent failure. It may want to restore the 'original' into the target language only with the consciousness of the impossibility to do so. One has the desire for translation because the 'untranslated' is absent in the target language. Translating a story from an Indian aboriginal language like Santali may start with an acknowledgement of the failure of its own politics. Translating a Santali story is necessary because of the absence of its experiential world in the target language. The translation becomes rich in its intent when the story points out to this absence and realizes the failure of such a project. In this context Santali author Sarada Prasad Kisku's "Chaora-Bhaora" translated by Nishant Choksi is a carefully selected story, having potential to exhibit the failure of transcribing the language and culture of a linguistically and culturally marginal group into English, the language of the masters - the colonizers and currently that of the neo-colonial Indian state.

The story revolves around the plot of a Maoist infested village where a Santali police officer Tambod Soren took charge with the conviction to find out the terrorist miscreants who indulged local people into insurgent politics and violence. Tambod being honest and dedicated in his work pulls up his sources to get into the heart of the matter. But the foundation of the problem was not identified despite cutting off all supply lines and closing down all extra-governmental supports of unknown and suspect origin. Tambod's character suggests a failure of the state orchestrated entanglement of underdeveloped tribal world and the so-called world of development. As a liminal figure between two worlds Tambod in the end is kept in charge in that area not for his efficiency but because of his Santali origin and knowledge of the case. The Maoist help that reached villagers through some mysterious source was ascribed to 'Chaora-Bhaora'. These words 
were a part of Santali folktale. They were mythical names invoked in crisis, calling for help. The governmental apparatus did not understand these words and looked for their specific connection with the case or real people with these names. Organized resistance of a militant group that helped the tribals was interpreted and translated into folkloric mythopoesis of the Santals. Tambod, the Officer-in-charge of the area as well as the local Block Development Officer, being from the same tribe, understood the folkloric significance of the terms but could not connect it with the present insurgent crisis. The native informant model of governance fails.

In the story the translator efficiently keeps these untranslated mysterious words 'Chaora-Bhaora' to suggest the permanent fracture between the brutally subalternized and silenced Santali world of knowledge and the so-called civilized world of policy making and governance. Resistance comes as a messianic call for help. The analytical ability of the system of policing fails to understand it. They ascribed an external source to insurgent problems. Nishant's experience as a linguistic anthropologist on Santali language and culture is reflected in his deep respect to untranslatability. The focus of the story suggests that it may have been selected for English translation also as an instance of the failure of 'communication'. Communication is often a key word of today's worldwidisation of the project of translation, more so in English hailed as the language of communication. The story is a failure to incorporate the experience of Santali lifeworld into the thoroughly bureaucratized language of the world of development which identifies insurgency and resistance as a problem external to the tribal society. The story shows even a Santali police officer cannot write back the meaning of the folkloric consciousness of their society to the managerial Indian nation state.

\section{Translator's Note}

Nishaant Choksi

Sarada Prasad Kisku (Kherwal Basia) was born in 1959 in Baspahari, West Bengal. His first published work was a drama "Khijlau" in Santali in 1983, the first drama in the Santali theater corpus to feature an all-women cast. He followed this up with other plays and poetry collections, however he is most well known for his contribution to Santali short stories and is considered one of the pioneers in the field. He has published over 7 significant short story collections in Santali, some of his most famous being Morekoturuiko (The Spirits--Five and Six, 1993); Chaora Bhaora (2007); and Kokormet'te (From the eyes of an Owl, 2011). Kisku has won several state and local level awards for his work.

Kisku's short stories often circulate around contemporary social and political themes affecting Adivasi communities like the Santals, often combining the hard realities of Adivasi life with magical realism, mystery, and intrigue. No more is this apparent than in the short story Chaora Bhaora, which relates the experience of a Santal policeman 
transferred to an unnamed, "insurgent-prone" Adivasi area, where he tries to find out who is behind the insurgency. His journey takes him deeper into the contradictions that characterize Adivasi life on the rural peripheries, and compels him to confront the tension between his duty to the state and his own ethical commitments.

The story was published in a Purulia-based Santali little magazine in 2007, and later formed the titular story in a collection published in 2008. Originally the story was popular as a mystery-thriller with a political connotation, but it proved prescient as in the next year, 2009, a Maoist insurgency began in southwest West Bengal, with many of the events eerily similar to those recounted in Chaora Bhaora. The story took on new relevance and popularity, and though it was written two years earlier, was featured as a response to later events in the popular press. This ironic twist, particularly the way media responded, is also foretold in the story's denouement.

\title{
Chaora Bhaora
}

\author{
Sarada Prasad Kisku
}

The officer-in-charge, Tambod Soren, a renowned name among the police, was courageous, intelligent, unyielding and strict with any thief, bandit, or other mischief-maker who crossed his path. With sheer determination, he controlled the powerful rock quarry mafia who were illegally occupying public land, and subdued the political big-men who were routinely creating chaos in the towns. He refused to obey the powerful, meddling politicians; neither did he ingratiate himself to higher-up officers. He was of strong mind, never derelict in his work, and never succumbed to the temptations of greed. Nobody was able to make him bend to his will. And as a result, he was constantly transferred, to whichever place his higher ups deemed the most dangerous and the least desirable, where there was constant fighting, and where constantly loomed the threat of death. Unswayed, Tambod gladly accepted the charge. He saw each transfer as a new opportunity to test and improve his personal performance. The repeated transfers had not so far dimmed in any way his willingness to take risks. But this time was different: this transfer orderunnerved him - he was being moved to the forest regions in order to lead the charge to catch and subdue the so-called 'terrorists.' On assuming the charge at the police outpost, he at once commenced the investigation. In order to construct an adequate description of the situation he was facing, heread through the police reports and sifted through back issues of the newspapers. This is the picture he constructed:

Two years ago, in one of the forest villages, a local political leader was shot dead in full daylight in plain sight of the villagers. The villagers were shocked, and naturally questions arose. Why did they kill him? Who killed him? They had never seen anyone killed like this before, instantaneously with a close-range bullet, and that too right in front of their eyes. At the markets and village fairs, and whenever and wherever people met, 
they would discuss the event at length; everyone trying to solve the mystery. But the answer to their questions arrived one day rather suddenly. That day, old newspapers were found pasted on the wall of a local tea stall with words scrawled over them in red ink. It said that because the targeted political leader had actively obstructed the development of the area he no longer remained in the world. It also warned that those enemies of the poor, those who stole food meant for the poor, the cheaters and frauds, would also receive their death sentence in due time. Finally, a few other names were listed -an omen of what may come next.

Fear descended over the village. One by one the leaders of the main political party were being assassinated. People were afraid, wondering why members of the ruling party were being targeted and what was it that the killers desired? Yet at the same time they also sympathized with the killers. Those who were being assassinatedwere entrusted with the responsibility of governing the forest villages, and ensuring the people's well being. Yetin that responsibility they were failures; government funds for building much-needed roads and providing irrigation to poor farmers were squandered and stolen. Instead that money was used to support the party and the activities of the party office. Some leaders even spent the money building homes, buying cars and motorcycles, or purchasing personal property. And not only that; because of party-politics villagers also fought among themselves. The villages' sacred groves, previously a symbol of unity and strength were divided along party lines. Brothers became enemies, and nobody heeded the advice of the village elders, or the traditional authorities. Political leaders were brought in even to solve disputes between husbands and wives. Marriages were arranged according to party considerations. The party became more important than family. As a consequence, the party leaders who, in their activities, sought to undermine the foundations of Santal society: the rituals, customary laws, and traditional village governance, also found their names on the target lists. It was no surprise then that local people were ambivalent that these leaders were being targeted and killed. Yet why would the government and police not be concerned? They were of course very anxious about the situation; the government sent many truckloads of police reinforcements to the forests, and commenced full-scale investigations to find and apprehend the murderers.

As part of the investigation, whenever police came across a local person in their midst, they would immediately arrest them. Even at midnight, police would scour the villages nestled deep in the hills and forests, bursting into homes in search of the terrorists, interrogating and torturing people, not even sparing women. Using the excuse of looking for weapons, they would forcibly rip off women's saris, and in homes with no men present, they would rape the young women who lived there. Witnessing this torture, young boys would try and stop the police from taking the honor of their mothers and sisters. The police, however, would shove them aside with the butts of their rifles. The stronger and intelligent children were immediately arrested. For two or three days they would be locked up at the police camp, suffering constant tortures. After that, if they could not find any reason to keep the child, they would release him. Yet, even under the watchful eyes of the police, two or three of the ruling party members had been killed. Pressure started coming from the higher authorities. By any means, these murderers and terrorists must be caught; otherwise, the police would lose their jobs. 
One day, having received news about a secret hiding place, the head officer of the nearby police station along with a police force went to a village nestled in the hills to catch the terrorists. Having crossed a mountain, the car was descending down a slope. Just in front of the river crossing, a bomb buried under the ground exploded, with a sound so loud that it cast a curtain of deafness over everyone's ears. Perhaps this was what they called a 'land mine.' In the jeep at the front of the convoy was the head officer. The bomb blew apart the jeep, flinging its parts up in the air like dried up leaves scattered by the wind. Along with the officer, four other police were killed. No intact corpses were found. Hands, legs, and other separated body parts were found hanging on branches of faraway trees. Never before had there been such a large-scale attack like this on the police. Before, whenever local people saw police cars, they would immediately run away. Today these same people are fighting against the police. Now the normally silent hills echoed with fear. Bullets exploded through each and every shrub and bush along the hillside. The news immediately reached all the surrounding police stations and camps. All the paramilitary battalions rapidly converged on the place of the incident, and then dispersed in teams over the whole area. Tents were set up not only at the police camps, but also at panchayat offices and schools throughout the region. The forest areas were finally given some importance in the media, making headlines in newspapers and news channels. The whole nation was now able to witness the situation in the hills, naked and uncensored. After 55 years of independence, the citizens of India had an opportunity to see the darkness in which the Adivasi people of this area lived. Here, the whole world now knew, that people still had nothing to eat; that they died of starvation. The people who governed this area, the Assembly members, and the members of Parliament were Adivasis, Santals, but even at hearing the news of this crisis and deprivations, they still felt no shame. These Parliament and Assembly members were elected to usher in the development of this area and to help address the problems of the Adivasi people, yet they had forgotten this charge. These naïve politicians made no demands in the State Assembly. The people in power, the government party felt no responsibility for this area and its development. They only did the bare minimum in order to maintain a relation with Adivasi people, as they needed their votes to maintain power. Now the area's earth reverberated with the sound of police vans, jeeps, bullet-proof heavy armor vehicles roaming far and wide. Paramilitary flag marches were conducted by the police. Everyday hundreds of thousands of rupees were being spent for the purpose of catching the terrorists. But not even two annas of this money were being spent for the well-being of the area. It was not true that there was absolutely no development. There was work being done. Even if the villages had no electricity or lights, there was a plan for a generator to give electricity to a few villages. But when this will happen was still uncertain. There were some holes dug for electric wire poles. But how many times would the people have to give up their votes in order for electricity to come, even that was unknown. New schools were not being built. And whatever schools were there were being turned into police stations, and police stations were being turned into police camps. New officers were being brought in to head these stations. Those mountain roads on which previously not even bicycles could ride were now being upturned and turned into black pitch roads. Now, those previously uncrossable mountain streams, over which previously the government would not even place a sloping rock on which people could 
cross, cement bridges were being built. Yet still contractors were not ready to work in the area. Tambod Soren, having heard about the recent events of this place, started thinking more about the situation. The ordinary folk of this area have now lost all confidence in the police. First, confidence must be restored in the minds of the people. Police should make friends with the people, show them that they are not there to be feared. They should help in addressing the worries and concerns of the people, convince the people they are here to restore peace. At the same time, they should take part in advancing the development of the area. But why would no contractor agree to do any work in the area?

There was a threat against any who performed work in the area.

--Who made this threat and why?

Your police version says that it was the terrorists. But why are you - the police not asking about the reasons behind their actions?

--But I need to know. Why are they not seeking actively development for this region. Please tell me.

Officer in charge Tambod Soren did not disclose with whom he was speaking. The person's name was kept a secret. In police language, he was the "source." But he also had another name, the one who limps, the "cripple." The cripple proceeded:

--That they do not want the development of this area is merely the propaganda of you the police and the ruling party. "Development" does not come just from building a few roads. Building schools, colleges, dams, and ponds to give those who can acquire some livelihood, to help farmers and to build small irrigation canals, so that farming can take place throughout the year - all these activities could be possible. Where are they not being done? These roads that are being built - they are not being built with good intentions. They are being built so that you police and paramilitary forces can easily bring your vehicles in to arrest the people that are fighting. After the police's work is finished, and in the future when these roads are damaged or worn out, nobody will repair them. For that reason, they have ordered all this work to be shut down. And that is why the people of this area are not objecting to this order. Because no development programme has been proposed at all. And no government officer is interested to find out the reasons for all of this. Nobody has even mentioned anything about the poverty and lack of resources in this area. You cannot find anything about this area mentioned in any newspaper. Nowadays outside people are learning about this place in a few newspapers here and there, and finally the elected representatives of the forests are feeling some slight sense of shame. People of this area hope that as this news spreads, the government in power will at the very least look at our situation more closely.

There was something different about what this source told him. He was speaking like the terrorists. How was he supposed to get information about the terrorists' secret activities? Yet he had to maintain the relation, so he carefully hid hissuspicions from the source. 
The paramilitary force commenced their operation under the leadership of their commander, without any assistance from the local police station. They were not confident in the local police leadership, and therefore began the hunt for the terrorists alone. At the same time, the local police started their own independent operation to catch the terrorists. One day, early in the morning, a red alert was broadcasted at all the local police stations and police camps. The van carrying the paramilitary forces had hit a land mine, exploding into pieces. The heavy steel engine, the steering wheel and the tyres - all the parts of the car had been shattered, flying far into the distance. Six paramilitary soldiers had died on the spot, their amputated limbs strewn about the site. Two soldiers had died on the way to the hospital, one died in the hospital. The rest of the force was hospitalized in critical condition. The police could not even imagine that an attack of such power and strength could have occurred here. Top to bottom, all officers and forces were placed on high alert. Everyone had the question, how did local police or the special investigation unit fail to anticipate this attack? Immense pressure was placed on the officer-in-charge, Tambod Soren. He was not able to provide any forewarning about the attack, nor was he able to catch any of the terrorists. Now, it would be difficult for Tambod Soren to keep his job. He became worried, and started thinking about what to do? He could not get any information about the attack or the perpetrators from anyone. But how would the police get information? Tambod Soren pleaded for just one more week. He promised that he would have something to show.

The police higher authorities could not understand from where the terrorists received these expensive and highly sophisticated arms used in these attacks, from where are these rifles, machine guns, and other high-powered weapons coming? Who is paying for these land mines? Who is training them to use these modern weapons? Who is directing them, giving them the power of mind and spirit to commit such audacious attacks? Who is the leadership? All intelligence agencies of both the state and central governments started surveying the area, searching for any answer they may find about the terrorists' secret activities, from any source they could find.

Tambod Soren worked on the investigation day and night. His source told him that the so-called 'terrorists' listed in the police notes are all members of a single political party. They have a political ideology, a political path. They believe that poor people should unite in a struggle against the rich. But they do not believe that this struggle can be won through elections. Right now, those in power maintain their power only by the barrel of a gun. Therefore, the only way one can fight this power is through armed struggle. And through armed struggle, they say, the poor can rise to power. They came to this area firstly as a political party, and are seeking to seize power on behalf of the poor. $90 \%$ of the area's leadership is selected by poor people. Here there are no big landowners, traders, merchants, or capitalists. The police and military are not here to protect the wealth of millionaires. The local people call the party the "forest party." Some also call them "forest nomads". To arrest them is very difficult. They do not stay in one place for more than a day. And even if you catch one or two, you will not get much information from them. You might see a comrade only once, and then never a second time. Nobody uses their real names. They do not feel that knowing addresses, or names of 
native villages are necessary either. They recognize each other only by their assigned role and job.

--But aren't people from these forests also involved? Who are they?

--They are villagers.

--Among these villagers, can you give me a name or two?

The source could not disclose this openly for various reasons. But Tambod had to make the source tell him. It was necessary for him to find out a few key points. For example, what was this group's agenda, and what were their vulnerabilities? Who was involved with them? Where do they stay? What do they eat? Who supplies them with weapons? If in a fight someone is wounded, or if someone is sick, who provides them with care and medicines? In addition to these questions, he also had to understand the situation from different angles so that he could see the whole picture. These questions were continuously running through Tambod's mind.

It did not even take one week. Two women fighters were captured. In each of their hands was a loaded AK-47 rifle. They were wearing uniforms in the exact manner of the police: khaki clothes, shoes, and hat. On their waist were ammunition belts. In no way did they look any different from a government military soldier. Only because they had temporarily separated from the group to take care of their feminine needs, were they able to be arrested. Tambod Soren had information from beforehand that the two women would be heading through the pass toward a mountain pool to bathe. Thus, Tambod Soren gathered a force together to ambush the women. For the police, arresting them was considered a great victory. They spread the news around the world. And this great victory occurred under the leadership of Tambod Soren. At the same time police were celebrating this victory, once again they were struck with a setback. The police "source" or the betrayer, the 'cripple' was murdered. Fear spread again throughout the hills. Now the police and paramilitary together united in the hunt for the terrorists. They began combing village after village. One or two more were caught by the police dragnet. SP (Superintendent of police) and IG (Inspector General) were hoping that they would be able to extract more substantial secret information. For that, police officers were called for meeting in each of the districts. In the meetings, it was said that the police investigation units should become more active in the gathering of information. And from those who have already been arrested, a more concerted effort was to be made to extract true information from them. For that, responsibility was given to the local police stations.

Since when have you been part of this action group?

--Around one year.

What is the name of the leader of this operation?

--I don't know.

What name do you all call him by?

--“Comrade."

Everyone is a comrade. What designation does this 'comrade' have?

--Area Commando One.

Where is he from? 
--I don't know.

What language does he talk to you all in?

--All languages.

In which language does he train you to use rifles, machine guns, etc.?

--Hindi, English. Sometimesalso Santali.

Is he a Santal?

--I can't say.

Where do the rifles and machine guns come from?

--I can't say.

Who gives you food, clothing, etc.?

--Comrade.

Do you personally know that comrade?

--No.

If you ever see that comrade would you recognize him?

--No. I only met that comrade once, but my eyes were blindfolded.

If you ever heard his voice, would you be able to recognize him?

--No. Because we never meet or speak with the same comrade twice.

Even after so much cross-examination, he still was not able to find out the truth. That was because these terrorists worked under a different kind of system. Each comrade would never meet the same group twice. Also, each comrade recognizes each other through a code word given by the previous comrade. For example, the current comrade would whisper in your ear, 'your code name is 'Akbar.' And the new comrade who will come would be given the name "Birsa," a name which only you know, and would not be disclosed to anyone. It is prohibited to write the code down, and one cannot forget it. For the provisioning of weapons or other important work, when you meet the other comrade, who calls out "Birsa" you must immediately tell your name "Akbar." If you are late in giving your answer, of if you don't answer correctly, it is possible you may lose your life. Except for this secret code, they do not have any other way of recognizing each other. This code can only be used once. Different people use different codes. Thus, even if one is tortured or beaten, one cannot give the names of comrades with whom they were associated. Getting accurate information was therefore very difficult.

He also failed to discover from where the terrorists were getting support. Because of this the police investigation hit a dead end. The higher authorities became very worried and impatient. Their opinion was that the hill area's lack of development was the reason for the increase in terrorism. For that, better relationships should be made with the local people through development projects. They directed the District Magistrate to sanction projects in their respective districts. But there was already development work being done by one of the Adivasi development NGOs in the area. This NGO was buying oxen for farmers for the purposes of tilling their fields, storing water from mountain streams so that people could farm in different seasons, and leveling rocky and sloped land so that it could be used for cultivation. They started building roads, dams, and ponds in different villages. They bought up pigs, sheep, and goats. They ran evening school for adults and morning school for children. For children, they would provide hot powdered milk in the mornings. And three times a week, they would bring in a doctor from the 
nearby citywho wouldlook at patients, and provide medicines for free. For unemployed boys, they would provide start-up money for business, and for girls, a machine to make leaf plates, and a sewing machine. The best part of this was that there were no formalities necessary; the process was very easy and straightforward. And nobody had to spend any money, nor did they have to return any of the expenses. All assistance was given as a donation. They also assisted the villagers in creating self-help groups which would pool money together and deposit it in the bank for the purposes of microcredit, and bought material for sports (such as shoes, pants, etc.) and instruments for tribal song and dance. Having seen all this, the District Collector was very surprised. Where was all this money coming from? Even the government was not capable of providing this kind of funding. Did they apply for or receive any kind of official permission certificate for undertaking these development activities? They did draw on a few already existing government programmes, such as the tree-planting scheme, sanitation, mid-day meal for schoolgoing children, and polio awareness. They implemented these programmes quite successfully. But except for these few programmes, where was the rest of the money coming from? The Block Development Officer (BDO) was directed to find out everything they could about this group and its activities. If a satisfactory answer was not received, all this NGO activity would be stopped.

The BDO began an investigation on the particulars of the members of this Adivasi development NGO. What kinds of work were they doing? From where are they getting money? What were their rules regarding the procurement and distribution of funds? Are they following government regulations?

But he could not get any satisfactory answers from any of the NGO workers. They were unable to say anything about from where the funding was coming. Whatever order came from their zonal office, they followed. The money also came from the zonal office.

Where is the zonal office?

There is an office in the name of the NGO in the district headquarters. What they learned from the zonal office was even more surprising. Payments were made in person and in cash, as were the expenses for all the ongoing projects. There was also a written list of how much money was to be given to other organisations and NGOs operating within the district. The only responsibility of the zonal office was to gather information about the activities of the various organisations of the district, and money that came to the office was only used to run the office with the rest distributed to the various organisations for various activities. The money was delivered by different people each time. As per their information, the money comes from the head office. The office was in Delhi. They did not know the mailing address of the head office. Actually, there was never any necessity to know. Because whenever there was a need for anything, somebody came by in person.

--Are these people Santals?

No.

--In what language do they speak?

Hindi or English. But they also know Santali, among other languages.

--Do you know their names? 
No. But sometimes when they speak, they use nicknames like Mr. Champa, Mr. Kharwar, Mr. Tata.

--If you saw them, would you be able to identify them?

I might be able to recognize one or two people.

After finding this out, the government stopped all development work in the area. The Adivasi development NGO was blacklisted. The poor people were helpless. Preparations for weddings which had been made with the help of these funds immediately ceased. Homes that were being rebuilt due to damage or wear remained half-done. Many people were distraught and angry at the government for stopping this work. The government could not do even a little bit of what this NGO was doing. Previously, the poor were given something, if only a little. If the work is good and helps people, then what does it matter whether it is legal or illegal?

The government's intelligence gathering units were directed to proceed with full force. Also, private detective agencies were enrolled by the government to gather information on all the NGOs operating in the area. The number of paramilitary camps was increased. Day and night, dust flew as vehicles constantly passed through the dirty roads of the area. A few local people were captured and brought to the police station. Then in a few days they were released. A few low-level leaders were also captured. However, there was not much hope that from these arrests they would receive much information, as they were all people from the area.

After conducting operations day and night for one month, the police came across some very important secret information. They came to know from where the money and arms were arriving. If they could stop this transit, then they could stop all the terrorist activities. Even if they did not have an address, they at least had a name. They could then find out the address. But before that, they must stop the transit of arms and cash to this area. They already stopped all the development programs of the area. But they could not find the way to stop the flow of armaments to the terrorists. Neither were they able to capture any of the leaders of the central committee. The SPs, DSPs, in-charge of various police forms, BDO of various districts were called for a meeting. The reason for the meeting was to find out how they could tackle the terrorist problem, and how they could restore confidence in the government among the local people. They accepted that even after so many years of India's independence, not everyone in the country has been given equal rights and opportunities. People have not had an equal opportunity to avail education. There is still starvation and malnourishment in villages. Roads, dams, ponds, wells for drinking water, schools, colleges, hospitals, were still woefully insufficient. Yet in spite of this, the method of the terrorists, to forcibly enter the area and kill people to accomplish their goals were inexcusable, they said, and they could not support it. The country's laws could not be broken by anyone. People who work outside the laws should be punished. Nobody is above the country's laws. They must make the people of the hill area understand that the government was ready to start all the necessary development work. It would be the responsibility of the BDO and officer-in-charge (police) to make this known to the public. For this, they would receive full backingfrom the government. 
The BDO said, "Sir, I cannot do my work without the help of the local gram panchayats. But you yourself have seen how they work. This is why the condition of the forest areas is like this. Even if I am a government officer, how much work can I alone accomplish? I am very doubtful about this plan."

The DMO responds, "BDO sahib, the government is ready to give you full and unconditional support in this work. The ADO (Agricultural Development Officer) will be with you as well. You two will work together with the panchayats."

Officer-in charge said, "In order to bring peace to the area, we must arrest the anti-social elements. But, in order to arrest them, we must rid ourselves from the unnecessary interference of the elected representatives, such as the MLAs and ministers. Yet, if we do this, how would the local people ever have confidence in the police?"

In order to make known the laws of the land, all kinds of powers were given to the police station officer-in-charge. In order to capture the real culprits, they would receive unconditional help and support from the higher officers. The government's responsibility was to ensure the peace, happiness and development of all citizens. The government exists to help the people address their problems and ease their sufferings. And the responsibility of government workers was to fully implement the government programmes for this purpose. All of us have to work together in order to accomplish this mission.

Intelligence officers reported, the net we cast during our operation has been more or less successful. But the name Chaora-Bhaora has been the thorn which has created the big hole in the net from which all the other fish can escape.

Who is this "Chaora-Bhaora?"

We intelligence officers still cannot understand. Is Chaora-Bhaora the name of two organisations? Or two individuals? All the support for these activities is coming from these two, Chaora and Bhaora. All the arms provided to the terrorists are coming from Chaora. While all the money for the Adivasi development NGO is coming from the Head office named Bhaora. But we cannot say for sure whether this Chaora and Bhaora are the names of persons or organisations. And we also cannot find any address for them either.

But the officer-in-charge and the BDO both understood the meaning of Chaora-Bhaora because they were Santals. We have heard these names generation after generation in winter harvest festival (Sohrai) songs and Santali stories. In Sohrai songs, these were the names of two extremely strong oxen. In addition, in ancient legends, Chaora and Bhaora were the names of two guard-dogs of a poor cowherd boy. Both the BDO and officer-in-charge heard these names from the stories of their grandparents when they were children. At the time, they did not try to understand the full meaning of this story. But nowit finally dawned on them the real meaning of story and the two names. Remembering the story, it was as if they could now hear the poor cowherd boy's crying 
sound enter their ears. Whenever the boy was in danger, the boy would cry out in song, “lelechaora,_lelebhaoradelase_delase_hijuk'ben_dhiri_godsini_sat_kapatteko_sin'_eset '_akadin'a." "Hey Choara, Hey Bhaora, come here, I have enclosed myself in a fort of stone."

Like vultures, the media gobbled up and spit out the news of "Chaora Bhaora." Now, as a result, today in the hills and forests, in the villages, in the mines and quarries, markets and towns, everyone is speaking of "Chaora and Bhaora." Santals, non-Santals, poor and rich, boys and girls, old people, police and military, officers and ministers, everyone wants to know what is the similarity between the "Chaora" and "Bhaora" of the Santali folktale and the conflict in hills? Is there any real relation with the song "Le_le_Chaora, le_le_Bhaora?" Even now, there is research going on. And for this, it was necessary to keep the officer-in-charge, Tambod Soren, at his post, even if his police operation was a failure. Tambod Soren kept his job. In his mind, Tambod Soren sang, "Le_le_Chaora,le_le_Bhaora."

samrat19802003@yahoo.co.in nishaant.choksi@iitgn.ac.in

(C) Sarada Prasad Kisku, Nishaant Choksi 